\title{
Impact of past and on-going changes on climate and weather on vector-borne diseases transmission: a look at the evidence
}

Florence Fouque* and John C. Reeder

\begin{abstract}
Background: The climate variables that directly influence vector-borne diseases' ecosystems are mainly temperature and rainfall. This is not only because the vectors bionomics are strongly dependent upon these variables, but also because most of the elements of the systems are impacted, such as the host behavior and development and the pathogen amplification. The impact of the climate changes on the transmission patterns of these diseases is not easily understood, since many confounding factors are acting together. Consequently, knowledge of these impacts is often based on hypothesis derived from mathematical models. Nevertheless, some direct evidences can be found for several vector-borne diseases.
\end{abstract}

Main body: Evidences of the impact of climate change are available for malaria, arbovirus diseases such as dengue, and many other parasitic and viral diseases such as Rift Valley Fever, Japanese encephalitis, human African trypanosomiasis and leishmaniasis. The effect of temperature and rainfall change as well as extreme events, were found to be the main cause for outbreaks and are alarming the global community. Among the main driving factors, climate strongly influences the geographical distribution of insect vectors, which is rapidly changing due to climate change. Further, in both models and direct evidences, climate change is seen to be affecting vector-borne diseases more strikingly in fringe of different climatic areas often in the border of transmission zones, which were once free of these diseases with human populations less immune and more receptive. The impact of climate change is also more devastating because of the unpreparedness of Public Health systems to provide adequate response to the events, even when climatic warning is available. Although evidences are strong at the regional and local levels, the studies on impact of climate change on vector-borne diseases and health are producing contradictory results at the global level.

Conclusions: In this paper we discuss the current state of the results and draw on evidences from malaria, dengue and other vector-borne diseases to illustrate the state of current thinking and outline the need for further research to inform our predictions and response.

Keywords: Climate change, Vector-borne diseases, Mosquitoes vectors, malaria, arboviruses

\footnotetext{
*Correspondence: fouquef@who.int

UNICEF/UNDP/ World Bank/WHO Special Programme for Research and

Training in Tropical Diseases (TDR), 20 Avenue Appia, 1211 Geneva 27,

Switzerland
}

(c) The Author(s). 2019 Open Access This article is distributed under the terms of the Creative Commons Attribution 4.0 International License (http://creativecommons.org/licenses/by/4.0/), which permits unrestricted use, distribution, and reproduction in any medium, provided you give appropriate credit to the original author(s) and the source, provide a link to the Creative Commons license, and indicate if changes were made. The Creative Commons Public Domain Dedication waiver (http://creativecommons.org/publicdomain/zero/1.0/) applies to the data made available in this article, unless otherwise stated. 


\section{Multilingual abstracts}

Please see Additional file 1 for translations of the abstract into the five official working languages of the United Nations.

\section{Background}

"Climate is traditionally defined as the description in terms of the mean and variability of relevant atmospheric variables such as temperature, precipitation and wind. Climate can thus be viewed as a synthesis or aggregate of weather." according to Goosse et al. [1]. These atmospheric parameters are of primary importance for the development and natural life of all ecosystems on our planet, but their influence separately or in combination is highly complex and variable. For this reason, in most situations, we can only approach this understanding through modeling [2]. Correlative models can add an understanding of which parameters are the most important ones in some special regions to explain the climate suitability for a vector or a host. Further, mechanistic models to describe the biological/ecological processes of the transmission are needed and are depending on detailed experimental work to study these processes, and parameters [3]. The climate of the different regions of the world is represented by averages over many years and has been classified into several groups with strong characteristics. Changes in the natural climate can occur at different time-scale, from tens to thousands of years. However, since we can report the climatic variables such as temperatures and precipitations more precisely in a time-based way (daily, weekly, monthly etc.) data show changes including the increase of temperatures, increase and decrease of precipitation and abnormal occurrence of extreme events [4]. How these changes will affect human health and the transmission of vector-borne diseases (VBDs) specifically is a question of great concern [5]. VBDs can be considered as whole ecosystems that include the vectors-pathogenshosts relationship, linked to specific environmental conditions [6]. The changes in temperature and precipitation, either in intensity, mean, minimum and maximum values, as well as the duration and the variability of the changes, will affect the environment in which the VBDs are transmitted. These environments may become more or less favorable to the vectors and/or the animal reservoirs, as well as disease transmission. The changes will also affect the human host by displacing populations due to drought or flooding, or by affecting agricultural practices and housing systems. The changes will also affect the bionomics of the vectors, in particular the insect vectors.

Over the past 50 years, the earth's climate has been affected by global warming, with an increase of surface, air and ocean temperature, resulting in the melting of glaciers and the rise of sea levels $[5,7]$. The increasing occurrence of extreme events hits most dramatically the poorest countries, already facing the worst infectious diseases situations [8]. The consequences of the climatic changes on public health are not fully understood. However, the risk of emergence of new transmission zones, including in developed countries, is great and emphasizes the need to build our preparations to face such events [9]. Although the causes and consequences of climate changes remains the subject of important discussions [10-12], there is a consensus on the necessity to develop and use new tools for more accurate prediction of the impact of the climatic variables on the different aspects of VBDs transmission [13]. In this paper, evidence will be provided on the impact of climate changes on vectors and VBDs transmission in different types of systems. However, some basic information on how the vectors are responding to temperature change is essential to a better understanding of the impact of the changes.

The insect vectors that transmit pathogens become infectious mainly after the ingestion of the pathogen through a blood meal on an infected host, followed by the pathogens amplification/circulation in the insect's body, before the vector become infectious [14]. In the case of mosquitoes and arboviruses transmission, the duration of this amplification is called the Extrinsic Incubation Period (EIP) and is strongly dependent upon temperature $[15,16]$. Consequently, the climatic conditions and fluctuations have a direct impact on the transmission of arboviruses. The vector competence is a key-factor that may allow or not the transmission and is genetically determined and climatically modulated [17]. Furthermore, insects are cold-blooded or poikilothermic organisms and cannot regulate their own temperature. Since specific body temperatures need to be reached to achieve essential biochemical reactions, the development and physiological functions of the insect is dependent upon the ambient temperature and requires a certain amount of heat to be completed [18]. The amplification of viruses into the mosquito body includes several physiological processes, unknown for many of them [19], but also related to temperature and heat accumulation [20]. The physiological processes in virus amplification start above a threshold temperature and are completed when the thermal constant is reached [21]. The measure of accumulated heat or thermal constant is well described by the physiological time concept and can be expressed through the degree-days method [22-24]. The numerous studies on the Extrinsic Incubation Period (EIP) examining constant and variable temperatures have shown that EIP decreases when temperature increases from a threshold until a maximum, above which the EIP increases again $[25,26]$. The impact of temperature changes on VBDs transmission can further have 
indirect effects such as the biting behavior, fecundity and survival of the vectors [27] and insecticide resistance [28].

Other climatic variables that strongly influence VBDs transmission are water-related, such as rainfall period, duration and abundance, and the humidity of the environment [29]. Although our knowledge of the physiological responses of the insect vectors to the climatic data is increasing, the evidence for changes in transmission are not easily found, both because they require inter-disciplinary studies in regions lacking the necessary expertise, and also because of a lack of adequate data on relationships between climatic variables and transmission parameters such as vectors bionomics including the biting behavior, the resting time for eggs maturation and many other life traits. Nevertheless, the studies presented below clearly show how climate change had an impact or is influencing VBDs transmission for some important diseases, such as malaria, dengue and other diseases in different geographical areas. The objective of this manuscript is clearly to provide available evidences on facts, consequently potential changes based on modelling from future scenarios are not included and discussed.

\section{Main text: a look at the evidence Impact of climatic variables on VBDs transmitted by mosquitoes}

To better understand which climatic variables are affecting the VBDs ecosystem and how, the literature was searched firstly on PubMed with the words "climate" and "mosquitoes" and "diseases", than the word "diseases" was replaced by the name of specific diseases such as "malaria", "dengue" and other diseases names. From all publications available, only those presenting direct evidences which were facts and situations with proof of relationships between vectors/diseases outcomes and climate changes, were selected to be included in the discussion. From the selected literature, further publications were sometimes referenced. The objective of this review was not to be exhaustive in referring to all existing direct evidences, but more to show which mechanisms were at work and how the changes/trends of the climatic variables are currently influencing the different vector-borne diseases systems. As an example, the cycle of a mosquito-transmitted pathogen is divided into two parts, one part is in the vector and the other part is in the host(s). In the host, the pathogen will find stable and suitable temperature conditions, since the host is regulating its own temperature. On the other hand, in the vector, the pathogen will find the suitable temperature conditions only if the mosquito vector is exposed to a favorable environment. As an example, the Aedes aegypti mosquitoes will amplify and transmit dengue viruses only if exposed to temperatures within the range of 20 to $35^{\circ} \mathrm{C}$ [30]. These suitable temperature conditions are one of the factors that may explain why the presence of a competent species for transmitting a pathogen is not sufficient for disease transmission, even if the pathogen is introduced in a new region. To better illustrate this, the numerous imported cases of dengue, chikungunya and Zika viruses in European countries from travelers do not result in frequent local transmission, even when the competent vector Ae. albopictus is present and active [31]. Further, the vector competence which is the intrinsic ability of a species to amplify and transmit the pathogen is mostly genetically determined and results from long co-evolution between the vector and the pathogen [32]. This competence is often confused with the vectorial capacity, which is the force of infection of a VBD in a host population [33]. Vector competence can be studied in the laboratory under forced climatic conditions and provides the basic understanding of the potential risks of transmission. On the other hand, the vectorial capacity can be estimated only from field conditions with specific parameters and provides an estimation of the real risks of transmission.

When environmental conditions are changing because of climate change, the genetically determined vector competence will not be affected, but the vectorial capacity may dramatically change and provide conditions that are more favorable to outbreak transmission. The vectorial capacity is a function of vector density, which is strongly related to rainfall patterns in the case of mosquitoes [34], of vector survival related to temperature and humidity [35], of the EIP also related to temperature, and of the biting behavior which was found to be both genetically determined and temperaturedependent [36]. None of these parameters fluctuate in the same way, making predictions very unreliable without a complete understanding of the relationships between each parameter and climatic data. However, in some situations, a trend dominates and the impact of climate on a VBD transmission can be determined. Further, since the insects cannot regulate their own body temperature, they are known to look for favorable micro-climatic conditions [37], which mean that the easily available outdoors meteorological data do not represent the true conditions to which the vectors are exposed. As an example, when female mosquitoes are resting in cool and humid places, they are not exposed to high temperatures and dry environments [38]. Consequently, the true understanding of how climatic changes are affecting VBDs is not easily achieved and subject to controversial hypothesis. Nevertheless, the evidence of impact on malaria, dengue and other VBDs presented in this paper should raise awareness and support the need of action to mitigate these effects. 
Evidence of the impact of climate change on malaria vectors and malaria transmission

One of the first pieces of evidence relating climatic warming to an increase in malaria incidence was reported from Rwanda in 1994, showing that an increase in the mean minimum temperature explained $80 \%$ of the variance in the monthly malaria estimates in high altitude areas [39]. This finding is consistent with the threshold effect of lower daily temperatures on the extrinsic amplification period. In the following years, malaria transmission was widely used as a model to study the potential effect of different climate scenarios on distribution and patterns of this disease [40-42]. In most of the models, an increase of malaria transmission was predicted under the current rate of global warming, but some models showed a decrease in malaria transmission, due to reduced overall vectorial capacity [43]. Nevertheless, the number of studies reporting the true impact of climate change on malaria is rapidly increasing. Warmer temperatures were found to affect malaria trends in highland regions of East Africa [44], with real changes larger than the predicted ones, probably due to concomitant effects of unknown factors. This evidence shows how difficult it is to assess the real impact of temperatures changes. Warmer temperatures are particularly affecting the Anopheles vectors distribution, such as the distribution of Anopheles arabiensis in the slope of Mount Kilimanjaro, resulting in a subsequent change in malaria distribution [45]. The same effect on vector distribution was also found for seven Anopheles species in Iran [46] and for An. gambiae in Madagascar [47]. To confirm these findings, an increase of malaria incidence at higher altitudes was reported in other countries such as Colombia and Ethiopia [48]. Variations in malaria incidence were also reported during the colder phases of the climatic phenomenon of la Niña in Venezuela [49]. In temperate regions moderately affected by malaria transmission, the effect of changing temperature is more complex. For example, in China malaria transmission is more sensitive to minimum temperatures under cooler climates and to maximum temperatures under warmer climates, with a longer lag effect in cool climate [50]. Consequently, an increase of minimum temperatures will increase malaria incidence in the northern parts, and concomitantly an increase in maximum temperatures will decrease malaria incidence in the southern parts.

Rainfalls and extreme flooding have also been found to have an impact on malaria transmission such as in Uganda, where an extreme flooding event resulted in an increase of malaria risk of 30\% [51]. In Zambia, an increase of malaria incidence was correlated to unusual rainfalls between 2008 and 2010 [52] and in Papua New Guinea, the seasonality of malaria was related to the rainfall in two different patterns according to the region.
A decrease of rain was associated with a decrease in malaria incidence in the southern coastal region, and at the opposite associated with an increase of malaria incidence in higher altitude [53]. Further, malaria trends in Papua New Guinea were associated to climatic factors at a very local scale with a great variability between locations [54]. Some concomitant effects of temperatures and rainfall were reported from Baringo county in Kenya, where an increase of rainfall was associated with an increase of malaria with a 2-month time lag, and an increase of maximum temperatures was also associated with an increase of malaria with a one-month (or less) time-lag [55].

The moving distribution of malaria vectors, as well as the fluctuations in malaria incidence are challenging vector control activities and impacting upon the malaria elimination targets in some countries. The evidence of changing patterns in malaria affected areas are not easily correlated to climate changes alone, since they take place in an overall changing situation, with modifications of land-use, water-management and human activities exposing different populations to different transmission patterns [56]. Further the potential impact of climate change on current vector control tools has not been properly studied and observations of changes in sleeping behavior when temperatures are rising at night time could have more impact on transmission patterns than the vector-related parameters. However, the evidence reported here clearly shows that climate change is affecting malaria transmission in different ways, challenging already fragile Public Health Systems and putting the human population at greater risks of outbreaks.

\section{Evidence of impact of climate change on dengue trends}

The monitoring of how climate changes are affecting some vector-borne diseases has not been performed systematically over long periods of time [57]. This is particularly true for dengue. However, some evidence has been collected in recent years, showing relationships between temperatures and rainfall changes and dengue transmission patterns. Dengue disease is mostly urban and transmitted mainly by the mosquito species Ae. aegypti. Urban temperatures are changing in a drastic way due to the warming climate and consequently they are enhancing, among other factors, dengue transmission and outbreaks, due to higher diurnal temperature range [58]. The combination of urban dynamics and climate change has been well studied in Singapore, where it was estimated that the increase of dengue incidence over the past 40 years, from less than 1000 cases in the 1980 s to more than 14000 cases in 2005 , was due to population growth for $86 \%$ of the model and to an increase on temperatures for the 
remaining $14 \%$ of the model [59]. This result clearly shows that even without population growth, an increase of temperature may result in an increase in dengue incidence. As previously seen for malaria transmission, the increase of the lower mean temperatures can be linked to an expansion of dengue transmission at higher altitudes and dengue incidence has recently increased in the mountainous country of Nepal [60] The first dengue cases were reported in 2006, followed by an outbreak in 2010, and the last epidemic was reported in late 2017, still ongoing in early 2018. The main city of Kathmandu which is above $1300 \mathrm{~m}$ is now affected by dengue outbreaks. In another region, further evidence was collected in Puerto Rico on the impact of increasing temperature on dengue incidence. An increase of $1{ }^{\circ} \mathrm{C}$ of the Sea Surface Temperatures (SST) was correlated to an increase of dengue transmission by a factor of 3.4 for the period 1992-2011 [61], and since warming for SST and air surface temperatures (AST) are now evident, a further increase in dengue incidence is expected.

In Vietnam a similar study looking at the impact of rainfall and increased humidity on dengue in the northern coastal city of Haiphong showed that dengue outbreaks are correlated to an increase of both climatic parameters. For each $50 \mathrm{~mm}$ rainfall increase and $1 \% \mathrm{hu}-$ midity increase, the risk of dengue outbreak increases of $1 \%$ [62]. These results are raising great concerns about the current changing patterns of climate in Vietnam, in particular in urban settings [63]. Interestingly, a strong decrease in rainfall followed by drought in Australia is also related to an increase in densities of Ae. aegypti mosquitoes, because of increased water storage [64]. This is a secondary effect of climate change linked to human behaviors. In Manila, that has a more tropical environment, dengue was correlated again to rainfall patterns only, with no impact of temperature variations [65]. Other climatic events were also found to be related to dengue cases, with mixed impact of increased temperatures and rainfall, due for example to the El Nino phases in Colombia enhancing dengue transmission [66]. Extreme events such as a tropical cyclone was associated with an increase of dengue incidence in four provinces of China [67]. The impact of climate change on dengue transmission can be more striking on the fringe of different climatic zones, as already mentioned for malaria. The increase of dengue incidence and expansion in Brazil was associated among other factors to climate changes in border areas between endemic and less affected areas [68]. The changes in climate patterns are making these areas more unstable for dengue transmission, with strong impact on Public Health Systems that have to regularly update the dengue transmission maps.

\section{Evidence of impact of climate change on other vector- borne diseases}

Other VBDs diseases are affected by climate change and the example of the human African trypanosomyiasis (HAT) or African sleeping sickness is very informative. This disease is linked to the presence of the tsetse flies vectors, which are very reactive to temperatures and rainfall patterns. The decrease in rainfall in the sahelian border of Western Africa since the 1950s has led to the displacement of the tsetse flies to the southern parts within the $1200 \mathrm{~mm}$ rainfall limit per year. Consequently the HAT has also moved from north to south and most of the remaining foci of HAT in the 2000s were found in the southern countries such as Ivory Coast, Ghana and Liberia [69]. Further, in a single country such as Burkina Faso, this shift from north to south could be measured and was estimated to be between 25 and $150 \mathrm{~km}$, with an estimated reduction of the tsetse belt of about 70000 $\mathrm{km}^{2}$ [70]. This strong decrease of the favorable environment for tsetse flies and HAT was attributed to both climate change, with severe droughts impacting not only the vectors but also the human distribution, and a strong human population growth modifying the tsetse habitats. A secondary and interesting effect of the climate change on the tsetse flies vectors is the fragmentation of the tsetse habitat which has an impact on flies dynamics and further reduce their densities [71]. More recently in another part of Africa, the increase of temperature was associated to the drastic decline in the tsetse flies densities in the Zambezi Valley [72], with a displacement of the vector populations to higher altitude areas (such as already seen in anopheles vectors and malaria) that are thus becoming more favorable to disease transmission. For another parasitic disease, the Leishmaniasis, transmitted by the sand flies, a shift in vectors distribution has been reported from south to north in Europe which is attributed to changes in the climatic conditions as modeled through an ecological niche approach [73]. Again, sand flies species competent for transmitting Leishmania parasites were recently found for the first time in Belgium and Germany, creating new risks of transmission in countries that are currently free of disease transmission. The same displacement of competent sand flies was also reported in the southern hemisphere, from north to south Argentina due to an increase of temperatures in more temperate regions of this country. This displacement was associated with new local cases of cutaneous leishmaniasis cases in the outskirts of the very populated city of Cordoba [74]. Consequently, the risk of extending the current transmission area of this disease in Argentina is very serious, and can be link to the climate change. In the case of leishmaniasis, the change in sand flies distribution due to climate change can also have 
consequences on the elimination program such as in Nepal for elimination of visceral leishmaniasis (VL). Between 1999 and 2009, 11 additional districts situated in mountains areas are reporting VL cases [60], and the country has now the obligation to extend the elimination program to newly affected areas, with all the costs and logistics issues for a low income country. The impact on climate change on VBDs transmission can be seen not only on the vectors, but also on the host such as in the Plague ecosystems, as demonstrated in the Daurian ground squirrel and Mongolian gerbil [75]. The first host densities are positively associated to vegetation, link to high temperatures and rainfalls. In the contrary the second host densities are negatively associated with vegetation. As a consequence, in the current climate change situation, the surveillance of plague foci in their natural environment is driven by the host behavior, which is very different for the 2 hosts, and a proper monitoring of the plague circulation with associated risks of emergence as human disease will now take into account the host densities link to vegetation link to climate change. Extreme events which are one the most important outcomes of the climate change trends have consequences on VBDs transmission other than malaria and dengue, such as in the case of Rift Valley Fever Virus (RVFV). The impact of the droughts and El-Nino/ Southern Oscillation (ENSO) events on the RVFV transmission has been well described, with rainfalls anomalies leading to the emergence of huge densities of vectors and outbreaks in the livestock and extension of the disease to humans, resulting in a double impact on very vulnerable human populations that are losing their livestock and facing the disease [76]. The improved current knowledge on the dynamics of this RVFV transmission patterns associated to climate events as well as community behavior is now allowing the prevention and mitigation measures [77].

\section{Conclusions}

Although it is not fully understood how climatic variables, changes in trends, extreme events and climate variability are directly affecting the transmission of vector-borne diseases, much evidence can be found to confirm that increasing temperatures due to global warming have an impact on these diseases. This evidence includes contrasting effects with increasing disease incidence in some situations and decreasing disease incidence in other situations. The same effects are also reported for livestock diseases, which have been studied more intensively because of their economic outcomes. For example, the increase in temperature is related to the expansion of some vectors and consequently of the diseases they transmit such as Culicoides imicola, transmitting the bluetongue virus, and on the contrary are also related to low survival of tsetse flies and a subsequent decrease of animal trypanosomiasis [76]. The consequences of rise of temperatures are thus not a one direction impact, and the VBDs ecosystems are responding in different and sometimes opposite ways. These findings reinforce the necessity to look at these changes with local and disease specific approaches.

One of the most common effect of climate change on VBDs is the change in vector and disease distribution found not only for malaria and dengue, but also for other diseases such as HAT, Leishmaniasis and the Japanese Encephalitis, now emerging as a human and livestock disease on the slopes of the Himalayan highlands [78]. Even in temperate regions, the displacement of VBDs has been reported and in Canada heatwaves were found to be related to the northern displacement of Lyme disease [79]. For Lyme disease, global warming has resulted in the tick vectors finding suitable conditions in northern areas, and also on the animal reservoir of Borrelia burgdorferi which are migrating northward and creating favorable conditions for Lyme disease transmission to extend to northern locations [80]. These changes in geographical distribution and expansion of the diseases will result in strong effects on the human and/or animal populations that are naive to the disease.

The impact of climate changes on VBDs is complex and the occurrence of opposite effects makes general predictions almost impossible. In order to provide recommendations, based on evidences that can be transformed into policies the impact of climate change has to be investigated at the very specific and local scale. Further integrated approaches are needed because of several confounding factors, which include the host behavior and human population dynamics (growth, mobility, ...). Nevertheless, the consequences of these changes already have an impact on Public Health, and the health systems need to be prepared to face epidemics and to mitigate these threats. Preparedness should be based on multi-sectorial concepts and framework, include a deeper understanding of the biological phenomenon as well as a plan for strengthening health systems to respond to different levels of emergency. The development of mitigation measures is needed at all levels, from the global to the local and should co-ordinate and take advantage of push to achieve the Sustainable Development Goals [81].

\section{Additional file}

Additional file 1: Multilingual abstracts in the five official working languages of the United Nations. (PDF $378 \mathrm{~kb}$ )

Abbreviations

AST: Air surface temperatures; EIP: Extrinsic incubation period; ENSO: El-Nino/ Southern Oscillation; HAT: Human African trypanosomiasis; RVFV: Rift Valley 
fever virus; SST: Sea surface temperatures; VBDs: Vector-borne diseases; VL: Visceral leishmaniasis

\section{Acknowledgements}

The authors want to thank Bernadette Ramirez and Pietro Ceccato for putting together this Special Issue, as well as all Principal Investigators and researchers of the research projects on the impact of climate change on the most vulnerable populations in dryland Africa, to increase resilience to Vector-Borne Diseases (VBDs), supported by TDR through funding from IDRC.

\section{Authors' contributions}

Both authors contributed to writing, editing and submitting the manuscript. Both authors read and approved the final manuscript.

\section{Funding}

Special thanks are given to the International Development Research Center (IDRC) of Canada for their support to TDR, the opportunity to manage research projects on the impact of climate change on the most vulnerable populations in dryland Africa, to increase resilience to Vector-Borne Diseases (VBDs) and the funding of the special issue on climate change and VBDs.

\section{Availability of data and materials}

The authors declare that all material and data used in the manuscript are referenced and freely available online.

\section{Ethics approval and consent to participate} Not Applicable.

\section{Consent for publication}

Not Applicable.

\section{Competing interests}

The authors declare that they have no competing interests.

Received: 9 July 2018 Accepted: 3 June 2019

Published online: 13 June 2019

\section{References}

1. Goosse H, Barriat PY, Lefebvre W, Loutre MF and Zunz V, (2008-2010). Introduction to climate dynamics and climate modeling. Online textbook available at http://www.climate.be/textbook.

2. Sofaer HR, Barsugli JJ, Jarnevich CS, Abatzoglou JT, Talbert MK, Miller BW, et al. Designing ecological climate change impact assessments to reflect key climatic drivers. Glob Chang Biol. 2017;23(7):2537-53. https://doi.org/10. 1111/gcb.13653

3. Tjaden NB, Caminade C, Beierkuhnlein C, Thomas SM. Mosquito-borne diseases: advances in modelling climate-change impacts. Trends Parasitol. 2018;34(3):227-45. https://doi.org/10.1016/j.pt.2017.11.006.

4. Snyder CW. Evolution of global temperature over the past two million years. Nature. 2016;538:226-8 (13 October). https://doi.org/10.1038/nature19798.

5. IPCC. In: Core Writing Team, Pachauri RK, Meyer LA, editors. Climate Change 2014: Synthesis Report. Contribution of Working Groups I, II and III to the Fifth Assessment Report of the Intergovernmental Panel on Climate Change. Geneva: IPCC; 2014. p. 151

6. Caminade C, Mclntyre MK, Jones AE. Climate change and vector-borne diseases: where are we next heading? J Infect Dis. 2016;214(9):1300-1.

7. Hansen J, Sato M, Ruedy R, Lo K, Lea DW, Medina-Elizade M. Global temperature change. Proc Natl Acad Sci. 2006;103(39):14288-93.

8. Patt AG, Tadross M, Nussbaumer P, Asante K, Metzger M, Rafael J, et al. Estimating least-developed countries' vulnerability to climate-related extreme events over the next 50 years. Proc Natl Acad Sci. 2010;107(4): $1333-7$.

9. Weissenböck H, Hubálek Z, Bakonyi T, Nowotny N. Zoonotic mosquitoborne flaviviruses: worldwide presence of agents with proven pathogenicity and potential candidates of future emerging diseases. Vet Microbiol. 2010; 140(3-4):271-80

10. Keller CF. Global warming: the balance of evidence and its policy implications: a review of the current state-of-the-controversy. Sci World J. 2003;3:357-411.
11. Eikenberry SE, Gumel AB. Mathematical modeling of climate change and malaria transmission dynamics: a historical review. J Math Biol. 2018;77(4): 857-933. https://doi.org/10.1007/s00285-018-1229-7.

12. Parham PE, Waldock J, Christophides GK, Hemming D, Agusto F, Evans KJ, et al. Climate, environmental and socio-economic change: weighing up the balance in vector-borne disease transmission. Philos Trans R Soc Lond Ser B Biol Sci. 2015;370(1665). https://doi.org/10.1098/rstb.2013.0551.

13. Tong S, Dale P, Nicholls N, Mackenzie JS, Wolff R, McMichael AJ. Climate variability, social and environmental factors, and ross river virus transmission: research development and future research needs. Environ Health Perspect. 2008:116(12):1591-7.

14. Wilson AJ, Morgan ER, Booth M, Norman R, Perkins SE, Hauffe HC, et al. What is a vector? Philos Trans R Soc Lond Ser B Biol Sci. 2017;372(1719). https://doi.org/10.1098/rstb.2016.0085

15. Watts DM, Burke DS, Harrison BA, Whitmire RE, Nisalak A. Effect of temperature on the vector efficiency of Aedes aegypti for dengue 2 virus. Am J Trop Med Hyg. 1987;36:143-52.

16. Reisen WK, Fang Y, Martinez VM. Effects of temperature on the transmission of West Nile virus by Culex tarsalis (Diptea : Culicidae). J Med Entomol. 2006; 43:309-17.

17. Severson DW, Behura SK. Genome investigations of vector competence in Aedes aegypti to inform novel arbovirus disease control approaches. Insects. 2016;7(4):58. https://doi.org/10.3390/insects7040058.

18. Dohm DJ, O'Guinn ML, Turell MJ. Effect of environmental temperature on the ability of Culex pipiens (Diptera: Culicidae) to transmit West Nile virus. J Med Entomol. 2002;39(1):221-5.

19. Girard YA, Popov V, Wen J, Han V, Higgs S. Ultrastructural study of West Nile virus pathogenesis in Culex pipiens quinquefasciatus (Diptera: Culicidae). J Med Entomol. 2005;42(3):429-44.

20. Reisen WK, Meyer RP, Presser SB, Hardy JL. Effect of temperature on the transmission of western equine encephalomyelitis and St. Louis encephalitis viruses by Culex tarsalis (Diptera: Culicidae). J Med Entomol. 1993;30(1):151-60.

21. Pedigo LP. Entomology and Pest management. 2nd ed. New York: Macmillan Publishing Company; 1991.

22. Baskerville $G L$, Emin P. Rapid estimation of heat accumulation from maximum and minimum temperatures. Ecology. 1969;50:514-7.

23. Wilson LT, Barnett WW. Degree-days: an aid in crop and Pest management. Calif Agric. 1983;37:4-7.

24. Huffaker CB, Rabb RL. Ecological Entomology. 1st ed. New York: Wiley; 1984.

25. Turell MJ, Rossi CA, Bailey CL. Effect of extrinsic incubation temperature on the ability of Aedes taeniorhynchus and Culex pipiens to transmit Rift Valley fever virus. Am J Trop Med Hyg. 1985;34:1211-8.

26. Turell MJ, Beaman JR, Tammariello RF. Susceptibility of selected strains of Aedes aegypti and Aedes albopictus (Diptera: Culicidae) to chikungunya virus. J Med Entomol. 1992:29:49-53.

27. Goindin D, Delannay C, Ramdini C, Gustave J, Fouque F. Parity and longevity of Aedes aegypti according to temperatures in controlled conditions and consequences on dengue transmission risks. PLoS One. 2015;10(8):e0135489. https://doi.org/10.1371/journal.pone.0135489.

28. Oliver SV, Brooke BD. The effect of elevated temperatures on the life history and insecticide resistance phenotype of the major malaria vector Anopheles arabiensis (Diptera: Culicidae). Malar J. 2017;16(1):73. https://doi.org/10.1186/ s12936-017-1720-4.

29. Chretien JP, Anyamba A, Small J, Britch S, Sanchez JL, Halbach AC, et al. Global climate anomalies and potential infectious disease risks: 2014-2015. PLoS Curr. 2015;7. https://doi.org/10.1371/currents.outbreaks. 95fbc4a8fb4695e049baabfc2fc8289f.

30. Carrington LB, Armijos MV, Lambrechts L, Scott TW. Fluctuations at a low mean temperature accelerate dengue virus transmission by Aedes aegypti. PLoS Negl Trop Dis. 2013;7(4):e2190. https://doi.org/10.1371/journal.pntd. 0002190.

31. Sigfrid L, Reusken C, Eckerle I, Nussenblatt V, Lipworth S, Messina J, et al. Preparing clinicians for (re-)emerging arbovirus infectious diseases in Europe. Clin Microbiol Infect. 2018;24(3):229-39. https://doi.org/10.1016/j. cmi.2017.05.029

32. Tabachnick WJ. Nature, nurture and evolution of intra-species variation in mosquito arbovirus transmission competence. Int J Environ Res Public Health. 2013;10(1):249-77. https://doi.org/10.3390/ijerph10010249.

33. Kramer LD, Ciota AT. Dissecting vectorial capacity for mosquito-borne viruses. Curr Opin Virol. 2015:15:112-8. https://doi.org/10.1016/j.coviro. 2015.10.003. 
34. Oo $\Pi$, Storch V, Madon MB, Becker N. Factors influencing the seasonal abundance of Aedes (Stegomyia) aegypti and the control strategy of dengue and dengue haemorrhagic fever in Thanlyin township, Yangon City, Myanmar. Trop Biomed. 2011;28(2):302-11.

35. Brady OJ, Johansson MA, Guerra CA, Bhatt S, Golding N, Pigott DM, et al. Modelling adult Aedes aegypti and Aedes albopictus survival at different temperatures in laboratory and field settings. Parasit Vectors. 2013;6:351. https://doi.org/10.1186/1756-3305-6-351.

36. Ngowo HS, Kaindoa EW, Matthiopoulos J, Ferguson HM, Okumu FO. Variations in household microclimate affect outdoor-biting behaviour of malaria vectors. Wellcome Open Res. 2017;2:102. https://doi.org/10.12688/ wellcomeopenres.12928.1.

37. Mandal R, Das P, Kumar V, Kesari S. Spatial distribution of Phlebotomus argentipes (Diptera: Psychodidae) in eastern India, a case study evaluating multispatial resolution remotely sensed environmental evidence and microclimatic data. J Med Entomol. 2017;54(4):844-53. https://doi.org/10.1093/jme/tjw232.

38. Omer SM, Cloudsley-Thompson JL. Survival of female Anopheles gambiae Giles through a 9-month dry season in Sudan. Bull World Health Organ. 1970;42(2):319-30.

39. Loevinsohn ME. Climatic warming and increased malaria incidence in Rwanda. Lancet. 1994:343(8899):714-8.

40. Martens WJ, Niessen LW, Rotmans J, Jetten TH, McMichael AJ. Potential impact of global climate change on malaria risk. Environ Health Perspect. 1995;103(5):458-64.

41. Lindsay SW, Birley MH. Climate change and malaria transmission. Ann Trop Med Parasitol. 1996;90(6):573-88.

42. Rogers DJ, Randolph SE. The global spread of malaria in a future, warmer world. Science. 2000;289(5485):1763-6.

43. Murdock CC, Sternberg ED, Thomas MB. Malaria transmission potential could be reduced with current and future climate change. Sci Rep. 2016;6: 27771. https://doi.org/10.1038/srep27771.

44. Alonso D, Bouma MJ, Pascual M. Epidemic malaria and warmer temperatures in recent decades in an east African highland. M Proc Biol Sci. 2011;278(1712): 1661-9. https://doi.org/10.1098/rspb.2010.2020. Epub 2010 Nov 10.

45. Kulkarni MA, Desrochers RE, Kajeguka DC, Kaaya RD, Tomayer A, Kweka EJ, et al. 10 years of environmental change on the slopes of Mount Kilimanjaro and its associated shift in malaria vector distributions. Front Public Health. 2016:4:281. https://doi.org/10.3389/fpubh.2016.00281.

46. Salahi-Moghaddam A, Khoshdel A, Dalaei H, Pakdad K, Nutifafa GG, Sedaghat MM. Spatial changes in the distribution of malaria vectors during the past 5 decades in Iran. Acta Trop. 2017;166:45-53. https://doi.org/10. 1016/j.actatropica.2016.11.001.

47. Tantely ML, Rakotoniaina JC, Tata E, Andrianaivolambo L, Fontenille D, Elissa N. Modification of Anopheles gambiae distribution at high altitudes in Madagascar. J Vector Ecol. 2012;37(2):402-6. https://doi.org/10.1111/j.19487134.2012.00244.x.

48. Siraj AS, Santos-Vega M, Bouma MJ, Yadeta D, Ruiz Carrascal D, Pascual M. Altitudinal changes in malaria incidence in highlands of Ethiopia and Colombia. Science. 2014;343(6175):1154-8. https://doi.org/10.1126/science.1244325.

49. Delgado-Petrocelli L, Córdova K, Camardiel A, Aguilar VH, Hernández D, Ramos S. Analysis of the El Niño/La Niña-southern oscillation variability and malaria in the Estado Sucre, Venezuela. Geospat Health. 2012;6(3):S51-7.

50. Xiang J, Hansen A, Liu Q, Tong MX, Liu X, Sun Y, et al. Association between malaria incidence and meteorological factors: a multi-location study in China, 2005-2012. Epidemiol Infect. 2018;146(1):89-99. https://doi.org/10. 1017/S0950268817002254.

51. Boyce R, Reyes R, Matte M, Ntaro M, Mulogo E, Metlay JP, et al. Severe flooding and malaria transmission in the Western Ugandan highlands: implications for disease control in an era of global climate change. J Infect Dis. 2016;214(9):1403-10 Epub 2016 Aug 17.

52. Bennett A, Yukich J, Miller JM, Keating J, Moonga H, Hamainza B, et al. The relative contribution of climate variability and vector control coverage to changes in malaria parasite prevalence in Zambia 2006-2012. Parasit Vectors. 2016;9(1):431. https://doi.org/10.1186/s13071-016-1693-0.

53. Park JW, Cheong HK, Honda Y, Ha M, Kim H, Kolam J. Time trend of malaria in relation to climate variability in Papua New Guinea. Environ Health Toxicol. 2016;31:e2016003. https://doi.org/10.5620/eht.e2016003.

54. Imai C, Cheong HK, Kim H, Honda Y, Eum JH, Kim CT, et al. Associations between malaria and local and global climate variability in five regions in Papua New Guinea. Trop Med Health. 2016:44:23. https://doi.org/10.1186/ s41182-016-0021-x eCollection 2016.
55. Kipruto EK, Ochieng AO, Anyona DN, Mbalanya M, Mutua EN, Onguru D, Nyamongo IK, Estambale BBA. Effect of climatic variability on malaria trends in Baringo County, Kenya. Malar J. 2017;16(1):220. https://doi.org/10.1186/ s12936-017-1848-2.

56. Kibret S, Lautze J, McCartney M, Nhamo L, Wilson GG. Malaria and large dams in sub-Saharan Africa: future impacts in a changing climate. Malar J. 2016;15(1):448. https://doi.org/10.1186/s12936-016-1498-9.

57. Kovats RS, Campbell-Lendrum DH, McMichael AJ, Woodward A, Cox JS. Early effects of climate change: do they include changes in vector-borne disease. Philos Trans R Soc Lond Ser B Biol Sci. 2001;356(1411):1057-68.

58. Misslin R, Telle O, Daudé E, Vaguet A, Paul RE. Urban climate versus global climate change-what makes the difference for dengue? Ann N Y Acad Sci. 2016;1382(1):56-72. https://doi.org/10.1111/nyas.13084.

59. Struchiner CJ, Rocklöv J, Wilder-Smith A, Massad E. Increasing dengue incidence in Singapore over the past 40 years: population growth, climate and mobility. PLoS One. 2015;10(8):e0136286. https://doi.org/10.1371/ journal.pone.0136286.

60. Dhimal M, Ahrens B, Kuch U. Climate change and spatiotemporal distributions of vector-borne diseases in Nepal--a systematic synthesis of literature. PLoS One. 2015;10(6):e0129869. https://doi.org/10.1371/journal. pone.0129869.

61. Méndez-Lázaro P, Muller-Karger FE, Otis D, McCarthy MJ, Peña-Orellana M. Assessing climate variability effects on dengue incidence in San Juan, Puerto Rico. Int J Environ Res Public Health. 2014;11(9):9409-28. https://doi. org/10.3390/ijerph110909409.

62. Xuan le TT, Van Hau P, Thu do T, Toan do TT. Estimates of meteorological variability in association with dengue cases in a coastal city in northern Vietnam: an ecological study. Glob Health Action. 2014;7:23119. https://doi. org/10.3402/gha.v7.23119.

63. Van Nguyen O, Kawamura K, Trong DP, Gong Z, Suwandana E. Temporal change and its spatial variety on land surface temperature and land use changes in the red River Delta, Vietnam, using MODIS time-series imagery. Environ Monit Assess. 2015;187(7):464. https://doi.org/10.1007/s10661-015-4691-3.

64. Trewin BJ, Kay BH, Darbro JM, Hurst TP. Increased container-breeding mosquito risk owing to drought-induced changes in water harvesting and storage in Brisbane, Australia. Int Health. 2013;5(4):251-8. https://doi.org/10. 1093/inthealth/iht023.

65. Su GL. Correlation of climatic factors and dengue incidence in metro Manila, Philippines. Ambio. 2008;37(4):292-4

66. Quintero-Herrera LL, Ramírez-Jaramillo V, Bernal-Gutiérrez S, CárdenasGiraldo EV, Guerrero-Matituy EA, Molina-Delgado AH, et al. Potential impact of climatic variability on the epidemiology of dengue in Risaralda, Colombia, 2010-2011. J Infect Public Health. 2015;8(3):291-7. https://doi.org/ 10.1016/j.jiph.2014.11.005.

67. Zheng J, Han W, Jiang B, Ma W, Zhang Y. Infectious diseases and tropical cyclones in Southeast China. Int J Environ Res Public Health. 2017;14(5). https://doi.org/10.3390/ijerph14050494.

68. Barcellos C, Lowe R. Expansion of the dengue transmission area in Brazil: the role of climate and cities. Tropical Med Int Health. 2014;19(2):159-68. https://doi.org/10.1111/tmi.12227

69. Courtin F, Jamonneau V, Duvallet G, Garcia A, Coulibaly B, Doumenge JP, et al. Sleeping sickness in West Africa (1906-2006): changes in spatial repartition and lessons from the past. Tropical Med Int Health. 2008;13(3): 334-44. https://doi.org/10.1111/j.1365-3156.2008.02007.x.

70. Courtin F, Rayaissé JB, Tamboura I, Serdébéogo O, Koudougou Z, Solano P, et al. Updating the northern tsetse limit in Burkina Faso (1949-2009): impact of global change. Int J Environ Res Public Health. 2010;7(4):1708-19. https:// doi.org/10.3390/ijerph7041708.

71. Wamwiri FN, Changasi RE. Tsetse flies (Glossina) as vectors of human African trypanosomiasis: a review. Biomed Res Int. 2016;2016:6201350. https://doi. org/10.1155/2016/6201350.

72. Lord JS, Hargrove JW, Torr SJ, Vale GA. Climate change and African trypanosomiasis vector populations in Zimbabwe's Zambezi Valley: a mathematical modelling study. PLoS Med. 2018;15(10):e1002675. https://doi. org/10.1371/journal.pmed.1002675

73. Chalghaf B, Chemkhi J, Mayala B, Harrabi M, Benie GB, Michael E, et al. Ecological niche modeling predicting the potential distribution of Leishmania vectors in the Mediterranean basin: impact of climate change. Parasit Vectors. 2018;11(1):461. https://doi.org/10.1186/s13071-018-3019-x.

74. Visintin AM, Beranek MD, Amieva MJ, Rosa JR, Almirón WR, Salomón O. Spread of Phlebotominae in temperate climates: province of Córdoba, 
Argentina. Mem Inst Oswaldo Cruz. 2016;111(1):75-8. https://doi.org/10. 1590/0074-02760150381.

75. Xu L, Schmid BV, Liu J, Si X, Stenseth NC, Zhang Z. The trophic responses of two different rodent-vector-plaque systems to climate change. Proc Biol Sci. 2015;282(1800):20141846. https://doi.org/10.1098/rspb.2014.1846.

76. Bett B, Kiunga P, Gachohi J, Sindato C, Mbotha D, Robinson T, et al. Effects of climate change on the occurrence and distribution of livestock diseases. Prev Vet Med. 2017;137(Pt B):119-29. https://doi.org/10.1016/j.prevetmed. 2016.11.019 Epub 2016 Dec 14.

77. Mutua EN, Bukachi SA, Bett BK, Estambale BA, Nyamongo IK. "We do not bury dead livestock like human beings": community behaviors and risk of Rift Valley fever virus infection in Baringo County, Kenya. PLoS Negl Trop Dis. 2017;11(5):e0005582. https://doi.org/10.1371/journal.pntd.0005582 eCollection 2017 May.

78. Baylis M, Barker CM, Caminade C, Joshi BR, Pant GR, Rayamajhi A, et al. Emergence or improved detection of Japanese encephalitis virus in the Himalayan highlands? Trans R Soc Trop Med Hyg. 2016;110(4):209-11. https://doi.org/10.1093/trstmh/trw012.

79. Ebi KL, Ogden NH, Semenza JC, Woodward A. Detecting and attributing health burdens to climate change. Environ Health Perspect. 2017;125(8): 085004. https://doi.org/10.1289/EHP1509.

80. Roy-Dufresne E, Logan T, Simon JA, Chmura GL, Millien V. Poleward expansion of the white-footed mouse (Peromyscus leucopus) under climate change: implications for the spread of Lyme disease. PLoS One. 2013;8(11): e80724. https://doi.org/10.1371/journal.pone.0080724 eCollection 2013.

81. United Nations General Assembly. Transforming our world: the 2030 agenda for sustainable development. UN Doc. A/RES/70/1. 2015. https:/www. unescap.org/2030-agenda. Accessed 27 Oct 2015.

Ready to submit your research? Choose BMC and benefit from:

- fast, convenient online submission

- thorough peer review by experienced researchers in your field

- rapid publication on acceptance

- support for research data, including large and complex data types

- gold Open Access which fosters wider collaboration and increased citations

- maximum visibility for your research: over $100 \mathrm{M}$ website views per year

At $\mathrm{BMC}$, research is always in progress.

Learn more biomedcentral.com/submissions 